\title{
EXPERIENCE IN DEVELOPING AN INNOVATION IN VIEW OF ITS SCIENTIFIC VERIFICATION AND THE PRODUCT PLACEMENT ON THE MARKET
}

\author{
Nikola P. Žegarac \\ Serbian Academy of Inventors and Scientists, Belgrade, \\ Republic of Serbia \\ e-mail: zegaracnikola@vektor.net, \\ ORCID iD: (iDhttp://orcid.org/0000-0002-1766-8184 \\ FIELD: engineering, energy, shipbuilding, automotive industry, \\ military industry, innovations, economy \\ ARTICLE TYPE: Original Scientific Paper \\ ARITCLE LANGUAGE. English
}

https://dx.doi.org/10.5937/vojtehg65-12215

\begin{abstract}
:
The paper presents an innovative device for dismantling and assembling parts of not-easily detachable assemblies of mechanical and electrical plants for on-site overhaul. The novelty is that the device offers fast and efficient dismantling and assembling of parts, without the possibility of damage. It is easy to use and easy to carry. It is used for all types of plants and higher levels of overhaul in field conditions. This quality device has been in the market for 4 years. The device is expected to be used over the next 10 years, and probably longer. Many years of experience in solving maintenance and repair problems resulted in this device for dismantling and assembly of mechanical and electrical assemblies. Many assemblies could not be dismantled and assembled in field conditions. The new device enabled developing a new technology of on-site overhaul and new methods of organization work and overhaul execution. It took only six months from an idea to its implementation due to producer's extensive experience in these and similar jobs. This innovative device is sold with the contractual obligations regarding the protection of the confidentiality of its construction and application.
\end{abstract}

ACKNOWLEDGMENT: The author would like to thank the organizers of the Competition for the best technological innovation NTI-2016, prominent experts who actively participated and significantly contributed to training competitors in the competition for the best technological innovation: dr Vesna Raškovic-Depalov, dr Đorđe Ćelic, mr Sanja Zagorac Knežević, and dr Viktorija Petrov. The results achieved in the field of innovation and creativity of our researchers, inventors and scientists, from the knowledge and research results to successful innovative enterprises, deserve the attention of the domestic and foreign public. 
The device is in the process of obtaining patent rights from the Intellectual Property Office in Belgrade, and after that it will be filled as an international patent application to the PCT.

Key words: innovation, new device, dismantling and assembly, not-easily detachable assemblies, overhaul, mechanical and electrical plants, mini hydro power plants, shipbuilding, military industry, business model, innovative company, techno-economic analysis.

\section{Introduction}

An innovative product, a complete device for dismantling and assembling parts of not-easily detachable assemblies on mechanical and electrical installations during on-site overhaul, is a new and original product in the country and the world. Research and development have been done as well as design, testing in the laboratory conditions and checking the functionality under field conditions in accordance with the requirements of the customer. Verification has been finished together with the certification and homologation of the system for the purpose of its application (Žegarac, 2012a). All device components met the required standards in the domestic and foreign markets (Žegarac, 2012b).

This new device for disassembling and assembling parts of not-easily detachable assemblies solves many problems in the field overhaul conditions. It is used for a higher level of overhaul in field conditions: intermediate level overhaul, general revision and general overhaul. Until now, in the country and the world, assemblies have been transported to specialized workshops or technical overhaul institutes for higher-level overhaul. In addition, existing devices are not applicable under field conditions on mechanical plants of different manufacturers. All this makes repairs significantly more expensive, up to $50 \%$, compared to the value of the overhaul itself. Operating systems are not in use for a long time, which causes significant production losses.

The universal new device can be used in many mechanical and electrical assemblies of various manufacturers, which is its main feature and advantage compared to the existing systems of a conventional type. The overhaul time is now significantly reduced, even up to 2 months if a general system overhaul is carried out (Tehnička dokumentacija firme Flender, 1975), (Tehnička dokumentacija za MHE, 1980).

The innovative device has enabled the development of a new, on-site overhaul technology, new ways of working in the organization and overhaul execution (Žegarac, 2012), (Žegarac, 2013). The device has been on the market for 4 years. Twenty sets have been delivered so far. The new 
device for dismantling and assembly has a wide range of applications: mechanical engineering, energy, automotive, shipbuilding, ship and vessel repair, aircraft industry, process industry, private firms that perform system maintenance and other industries. Potential market is not saturated. It is estimated that about 5.000 sets of various tools from over 80 manufacturers in the world are used to carry out overhaul. Such tools are not effective in field conditions. There is a continuous need to purchase high-quality devices and equipment. It is expected that, in the next 5 years, the sales of the new device will increase for 200 to 300 sets. In addition to purchase, customers often engage the manufacturer of this innovative product to make a higher level of service repair, which represents a significant inflow of profits for the company. Additional delivery of 30 sets is planned in 2017. Customers are electro industry, private companies and steel producers. The plan is to sell at the market of the Republic of Serbia, for the needs of the Electric Power Industry of Serbia (EPS) and several private companies. Years of experience in sales, application of the device for dismantling and assembling parts of not-easily detachable assemblies and providing overhaul services have helped in recognizing customer requirements. The innovative company can perform all forms of on-site overhaul. Customers are very satisfied with customer care and personal support. Selling a dismantling and assembly device is performed through the Know-How system.

Customers are mainly contacted in the public and on sites. So far, there have been no complaints regarding the new device and the repair service. The company possesses the necessary technical, financial, intellectual, market and human resources for the job. It has more than 30 years of professional experience. Key partners produce high-quality components to customers' satisfaction. The company has a highly qualified and professional staff to perform all types of repair and overhaul. The company has 12 employees, out of whom three make a special team. One of them is an academic, patent engineer, engaged in research and development and design of mechanical and electrical systems; as a team leader, he provides jobs on the market and cooperates with many companies. He participates actively during the overhaul of mechanical and electrical installations. He also performs the function of supervisory authority in the company affairs and monitors whether customers are satisfied with the quality of devices, installation and services. The second team member is a specialist for the repair of thermal power plants, hydro power plants, nuclear plants and other complex technical systems. He finished secondary school of mechanical engineering and secondary electro-technical school, has all authorizations and licenses to work in our country and abroad, overhauls mechanical and electrical systems and other complex systems. He mana- 
ges the team that carries out repairs of plants. The third team member is an MSc specialized in the installation and repair of electric power systems, a specialist in electric power plants and control. He has all authorizations and licenses to operate in the country and abroad. He performs tasks as an electrical engineer. The team has demonstrated success in previous sales of the device and in providing services of technical maintenance of mechanical and electrical installations.

This innovative device solves numerous problems in repair both in field conditions and in specialized workshops. The innovative company builds its competitive advantage on simplifying the technology of higher level overhaul, increasing the quality and reliability of plants in operation and reducing overhaul cost and time by $50 \%$. The possibility of damage to the parts during dismantling and assembly is excluded. The price of the dismantling and assembly device is acceptable to customers (6.000 Euros).

In the process of device production and delivery, the innovative company charges the value of the production materials in advance. The rest of the payment is made within 30 days upon delivery to the customer's warehouse. The profitability threshold is achieved by sales of 2 device sets (Petrov, 2016a). The first year of operation covered all costs. The business model is highly profitable, the level of security is such that the business model can withstand drastic market turbulences without any loss. The company is planning to deliver about 300 equipment sets at domestic and foreign markets over the next 5 years. All variable and fixed costs of the company are also covered.

\section{Part I - Innovation The novelty of the innovative device}

This universal device enables overhaul of assemblies of different manufacturers in field conditions. It has a wide range of applications, which until now was not the case. The universality of the device in application is achieved through various combinations of its components, which does not mean that the number of components is increased, but it means that individual components are constructed and adapted to cover a variety of sizes and dimensions of many assemblies being overhauled.

Analysis of the current state of technical installations

Many owners of mechanical and electrical installations require that technical maintenance and repair be performed in their plants, which greatly complicates the work. Technical maintenance of systems includes activities in the area of operational (basic) maintenance, light repair, inter- 
mediate repair, general overhaul and general plant overhaul. Operational maintenance and light repair are performed mainly by the users of the system. Many mechanical and electrical assemblies are transported to specialized workshops or overhaul depots for dismantling and reassembling parts being replaced. Almost $60 \%$ of assemblies could not be repaired on the spot. Besides, the transport of some assemblies is very complex, and there are many problems during loading and unloading, and security measures during transport. This used to consume a lot of time for system repair and maintenance, which significantly increased overhaul costs, in some cases up to $50 \%$. In addition, there are significant losses in production since the plant is out of operation for a longer period, especially in cases such as hydro and thermal power stations and other production systems.

The innovative device for dismantling and assembling not-easily detachable mechanical and electrical assemblies has been adapted to field conditions providing that all aspects of maintenance and overhaul can be performed on site. This universal innovative device can be used for the repair of many mechanical and electrical installations of various manufacturers such as German companies: Flender, Siemens, Vulkan, Stromag, Ossenberg, Geislinger, AEG, FAG, SKF and many others. These companies are the largest manufacturers of assemblies for the systems of large hydro power plants and mini hydro power plants, where this innovative company provides services of technical system maintenance. These mechanical and electrical assemblies make a whole system, and it is therefore necessary to have such a device available.

The innovative device is modular and can also be used in other types of plants. In the application of the device, the device elements are selected and combined, depending on the type and dimensions of components thus solving the overhaul problems. The device is easy to use and easy to carry. Systems for dismantling and assembling of domestic and foreign manufacturers do not have such characteristics. The main drawback of the existing devices is that they cannot be used in the field conditions. In addition, each manufacturer has adapted the dismantling and assembly of parts for their own plants, so they cannot be applied to plants of other manufacturers. Such systems are some kind of special tools, devices or equipment.

\section{Innovative product and service}

The unit of a new product is a set for dismantling and assembling mechanical and electrical assemblies. At the same time, buyers are provided with quality services and technical maintenance of the system. The 
new device allows easy, fast, high-quality disassembly and assembly of parts of not-easily detachable mechanical and electrical assemblies, on the spot. The innovative device consists of 3 parts (Figure 1).

A - Mechanical and hydraulic parts of the device
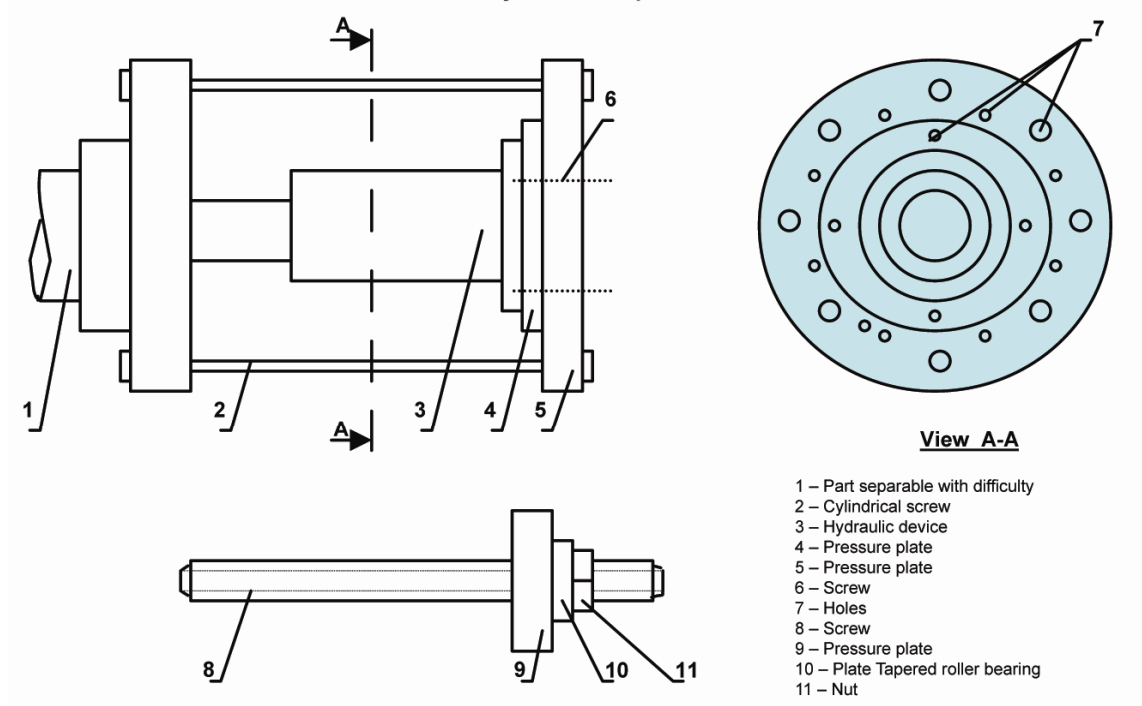

B - hydraulic components and units for device heating
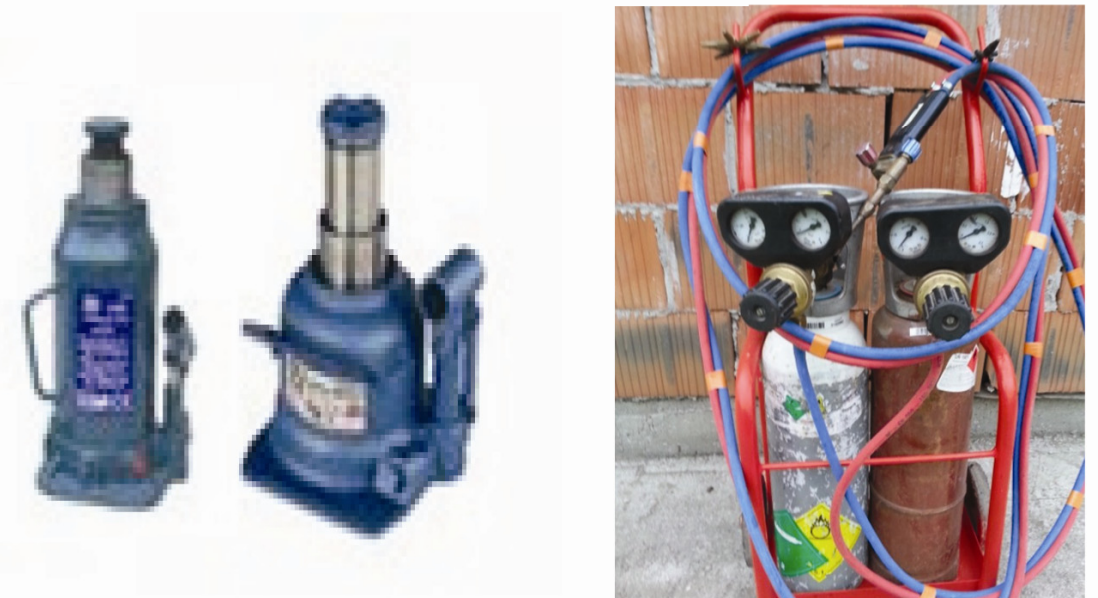

Figure 1 - Device for dismantling and assembling not-easily detachable mechanical and electrical assemblies

Puc. 1 - Монтажно-демонтажное устройство для сложно разбираемых узлов машиностроительного и электротехнического оборудования Слика 1 - Приказ уређаја за демонатжу и монажу тешко растављивих машинских и електросклопова 
The first part consists of mechanical components, the second part is a hydraulic unit and the third part is a unit for heating parts of mechanical and electrical assemblies which are dismantled and re-assembled. The device is used in all areas where mechanical and electrical assemblies are used. In electrical installations there are also built-in machine elements which after a certain period of exploitation should be replaced. For example, bearings of generators and electric motors, damaged covers and frames of assemblies, seals and many other parts of these plants. On several occasions since 2002, the innovative company has conducted, for the Electrical industry Montenegro, technical maintenance services based on overhaul plans at 18 mechanical and electrical plants: intermediate repair, general revision and overhaul. Within overhaul services, vibration analyses and vibration measurements were performed, as well as vibrodiagnostics, dynamic balancing of systems, laser alignment of assemblies, thermal imaging measurements (remote measurement of temperature at certain plant points) and others. The innovative company performs intermediate repair every 3 years in prescribed intervals, general revision every 4 years and overhaul after 6 years. Systems of mini hydro power plants are in continuous operation when there is sufficient water, i.e. in the period from late September to early June. In addition to regular overhaul activities, the company had to deal with damage to plants due to uncontrollable groundwater flows. Concrete foundations of assemblies broke resulting in major damage to assemblies.

Figure 2 presents the damage to a flange of flexible couplings ARPEX series K 430, size $270 \mathrm{~mm}$ on the flywheel shaft (right side in Figure 2), of the German manufacturer Flender. The flange was damaged due to inadequate removal. There were visible hammer blows and the distorted flange rim, which, during mini hydropower operation, causes elastic couplings to break with a possible breakdown of the entire system due to the dynamic unbalance and misalignment of the drive shaft.

Figure 3 presents a boken flange on the generator shaft of a mini hydro power plant due to improper dismantling and assembly of parts. Overhaul service had been carried out by companies not sufficiently specialized, professional and equipped to carry out complex overhaul tasks. 


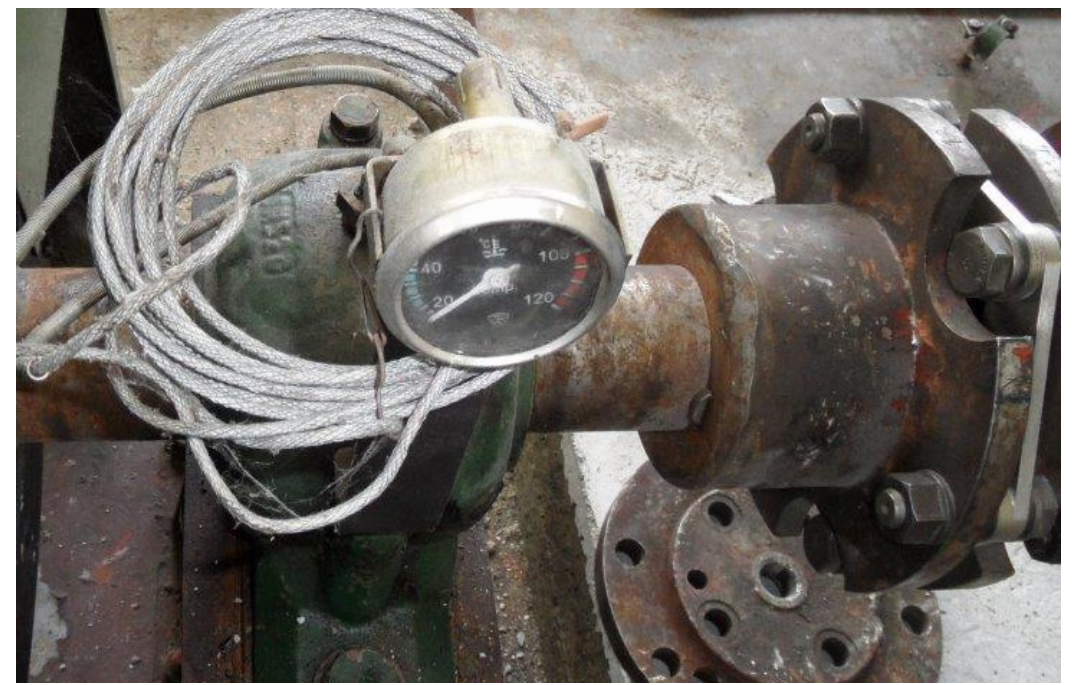

Figure 3 - Broken flange of the elastic coupling on the mini hydro generator flywheel Puc. 3 - Изображение сломанного фрланца упругой муфты на оси генератора мини-ГЭС Слика 3 - Приказ поломљене прирубнице еластичне спојнице на осовини генератора мини-хидролектране flange of flexible elastic couplin
of a mini hydro power plant Puc. 2 - Изображение повреждений фрланца упругой муфты на оси маховика мини-ГЭС Слика 2 - Приказ оштећења прирубнице еластичне спојницие на осовини замајца мини-хидроелектране

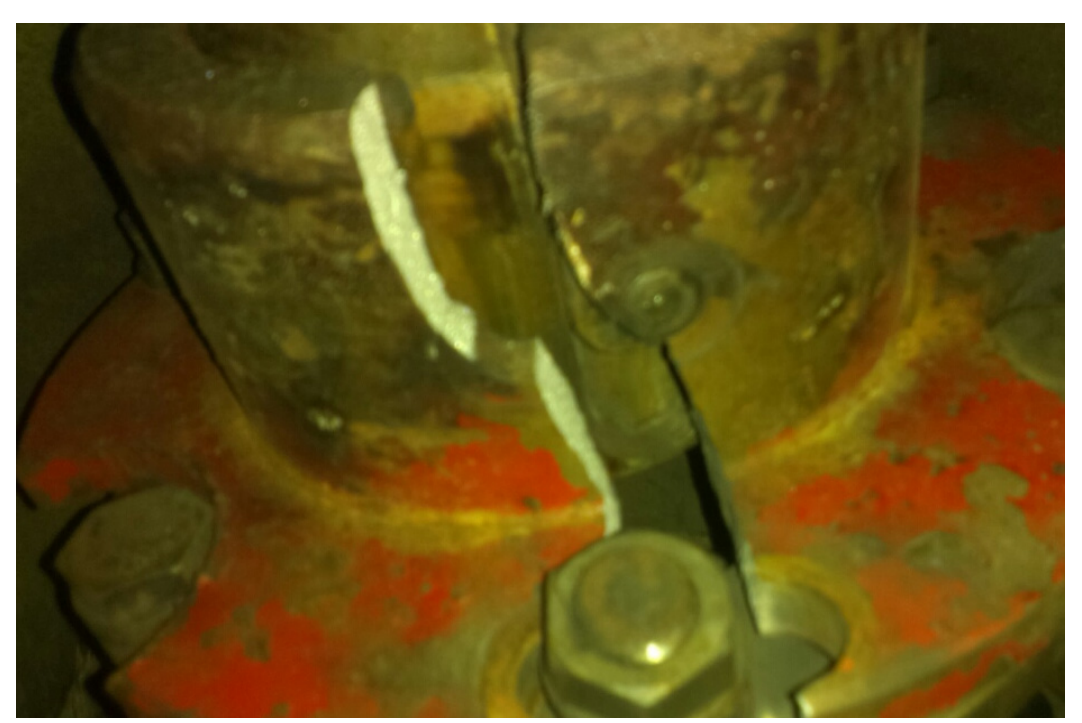


Figure 4 presents a mini hydro power plant flywheel damaged due to inadequate removal. The lower wedge for a clamping screw on the underside of the flywheel (left side of Figure 4) was broken. The "naked" screw that has no tightening function can be seen. Huge damage was inflicted. Creating a new flywheel is very complex, expensive and timeconsuming with a foreign manufacturer. Installing a new flywheel on a mini hydro power plant requires dynamic balancing and vibration measurements.

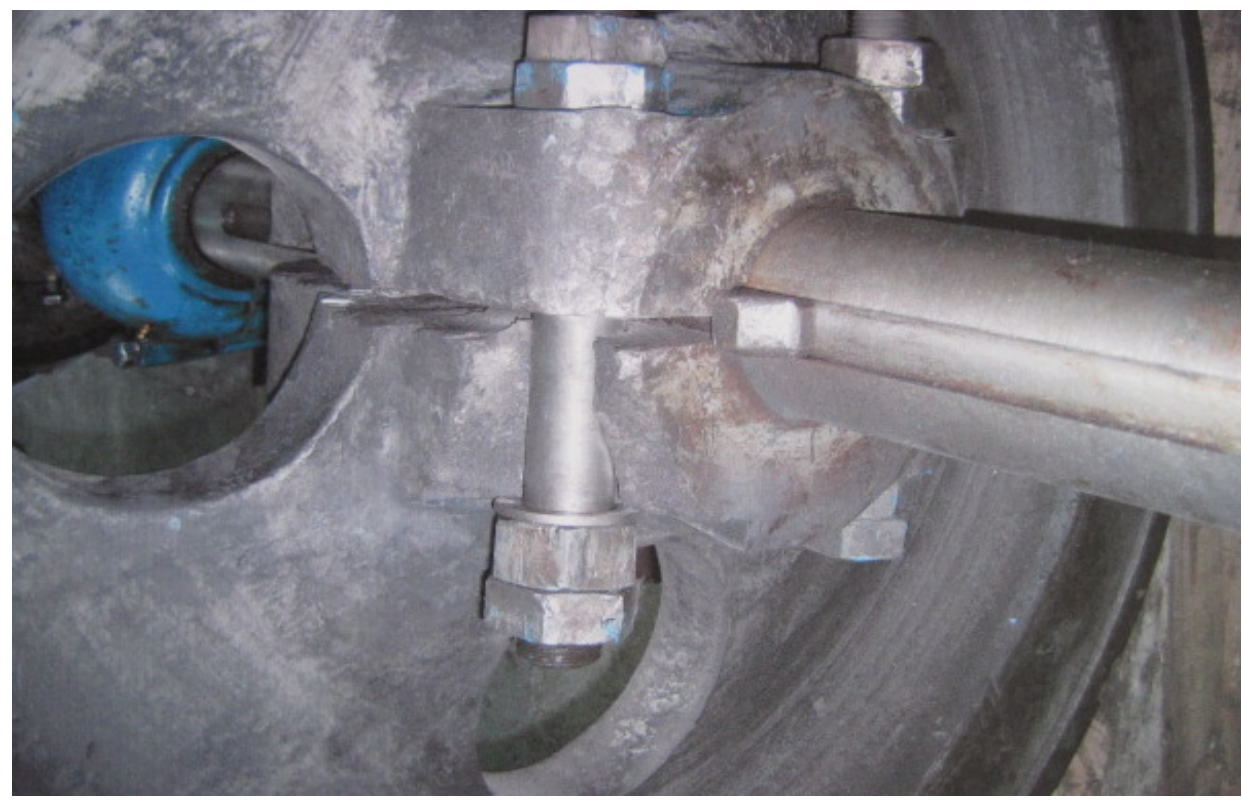

Figure 4 - Damaged flywheel of a mini hydro power plant

Puc. 4 - Изображение повреждений маховика мини-ГЭС

Слика 4 - Приказ оштећења замајца мини-хидроелектране

Figure 5 presents a high-quality assembly in the aggregate hall of a mini hydro power plant on the site, (view to right), using the new device for dismantling and assembling mechanical and electrical assemblies. A part of the assembly device and the device heating unit can be seen. A part of Flender couplings N-EUPEX type 480 is mounted on a new mechanical assembly, the drive shaft of the plant multiplier produced by Flender, Germany. The second half of the coupling is mounted on the turbine shaft of the hydro power plant. 


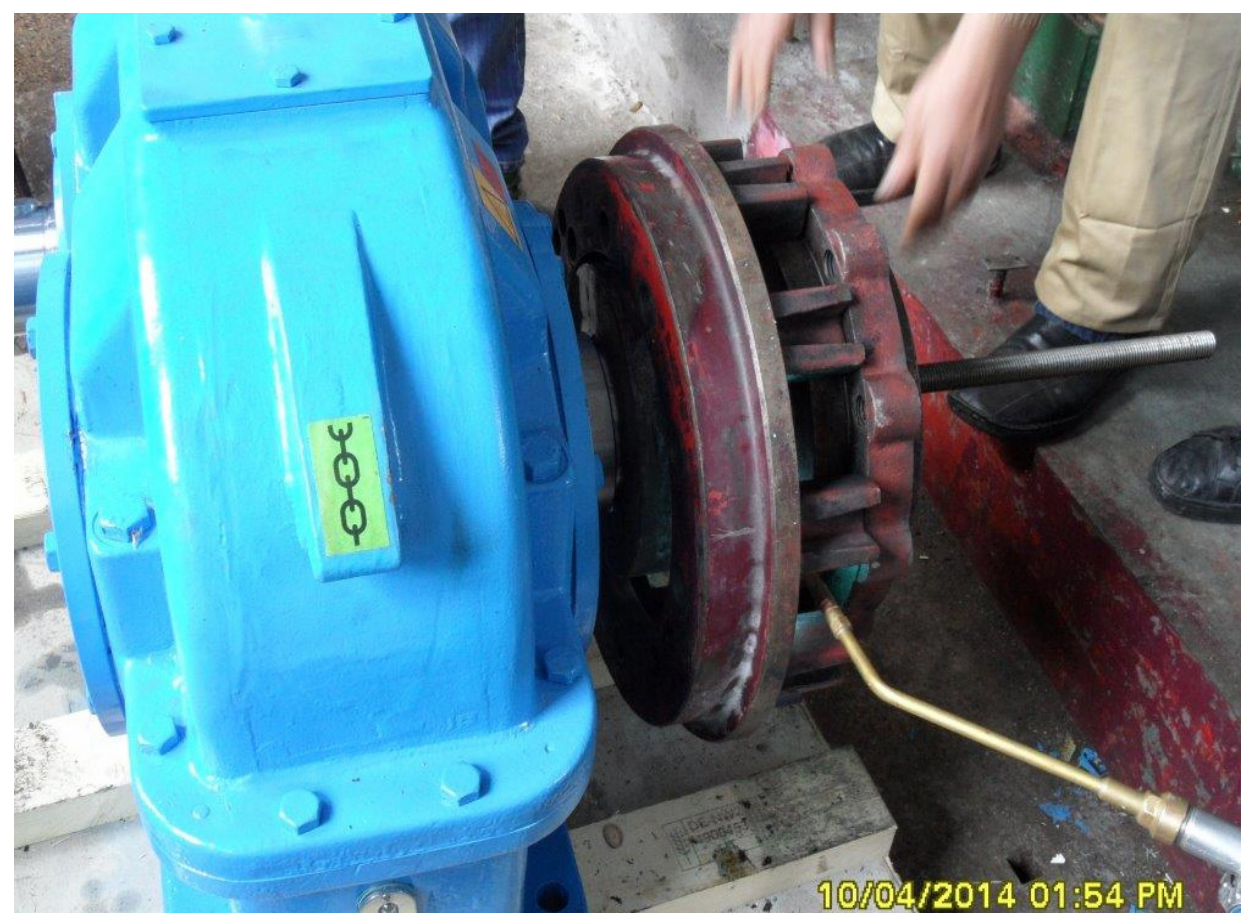

Figure 5 - High-quality installation of assemblies using the new device for dismantling and assembling

Puc. 5 - Изображение качественной сборки узлов с помощью нового монтажно-демонтажного устройства

Слика 5 - Приказ квалитетне монтаже склопова помоћу новог уређаја за демонтажу и монтажу

Previous sales and many offered services of technical maintenance of mechanical and electrical plants have proven successful use of the device. The appendix, Business Model, shows the Minutes on providing overhaul services in the Electrical industry Montenegro (Annex 1 and Annex 2).

\section{Market potential of the innovation}

\section{Market size and market potential}

The innovative device for dismantling and assembling has wide possibilities of application: power plants, thermal power plants, nuclear power plants, aviation industry, turbine systems in the process industry, ships, reciprocating compressors, gas turbines, automotive industry, internal combustion engines, diesel generator sets used as a backup source of 
power supply, machine tools, steel mills, mines, and many other plants where it is necessary to install new mechanical elements, or dismantle assemblies for replacement of worn or damaged system parts. Potential customers of the innovative product and services are companies engaged in the production and technical maintenance of mechanical and electrical installations.

Potential customers are also owners of mechanical and electrical installations in mechanical engineering, energy systems, automotive industry, shipbuilding and repairs of ships and other vessels, steel mills, cement plants, process industry, technical overhaul institutes and many others.

There is a continuous need for the procurement of new devices and equipment. So far, customers have been buying systems with a variety of special tools, equipment and accessories for dismantling mechanical and electrical installations, which are not universal. Complex forms of plant maintenance were carried out in specialized workshops or technical overhaul institutes.

Such devices were more like toolkits. Sets of tools are strictly personalized - each plant has its own set of tools.

Tools can be used for operational maintenance and some works in the field of light repair. They did not meet the requirements and conditions of a higher overhaul level. It is estimated that there are around 5000 sets of tools currently used.

Works in ship repair are important in particular. There is limited space available for overhaul works. The propulsion systems of ships are especially challenging: diesel engines, gearboxes, various flexible couplings, replacement of the shaft bearings, or replacement of the shaft bearings on the propeller.

It is expected that sales could grow by 200 to 300 pieces of equipment sets for dismantling and assembly.

In its previous work, the innovative company was particularly involved in the systems of mini hydro power plants in the Electrical industry Montenegro. Twenty devices have been delivered, out of which 18 are in the system of maintaining mini hydro power plants and 2 devices are used in HPP Piva and HPP Perućica for the repair of water pumps.

Table 1 shows the placement of the new product, the market size and the market potential. 
Table 1 - Market size and market potential

Таблица 1 - Размер рынка и рыночный потенциал

Табела 1 - Величина тржишта и тржишни потенцијал

\begin{tabular}{|c|c|c|c|c|}
\hline $\begin{array}{l}\text { For the needs } \\
\text { of } \\
\text { electroindustry, } \\
\text { large } \\
\text { hydropower } \\
\text { plants, mini } \\
\text { hydropower } \\
\text { plants and } \\
\text { pumping plants }\end{array}$ & $\begin{array}{l}\text { For the needs } \\
\text { of } \\
\text { electroindustry- } \\
\text { thermal power } \\
\text { plants and } \\
\text { pumping plants }\end{array}$ & $\begin{array}{c}\text { For the } \\
\text { purposes } \\
\text { of } \\
\text { shipbuilding, } \\
\text { repair of ships } \\
\text { and } \\
\text { other } \\
\text { vessels }\end{array}$ & $\begin{array}{l}\text { For the needs } \\
\text { of automotive } \\
\text { industry, } \\
\text { process and } \\
\text { aerospace } \\
\text { industries, } \\
\text { cement } \\
\text { factories, mines } \\
\text { and other } \\
\text { customers }\end{array}$ & $\begin{array}{l}\text { For the needs } \\
\text { of other } \\
\text { customers: } \\
\text { utilities public } \\
\text { enterprises, } \\
\text { technical- } \\
\text { overhaul } \\
\text { institutions } \\
\text { and other } \\
\text { customers }\end{array}$ \\
\hline $\begin{array}{l}100 \text { sets of } \\
\text { equipment }\end{array}$ & $\begin{array}{l}60 \text { sets of } \\
\text { equipment }\end{array}$ & $\begin{array}{l}70 \text { sets of } \\
\text { equipment }\end{array}$ & $\begin{array}{l}40 \text { sets of } \\
\text { equipment }\end{array}$ & $\begin{array}{l}30 \text { sets of } \\
\text { equipment }\end{array}$ \\
\hline
\end{tabular}

\section{Competition analysis}

On the domestic market and the market of the neighboring countries, there are reputable companies, manufacturers of mechanical and electrical systems, such as Siemens, AEG, Flender, Stromag, Geislinger, Voith Andreas, Uljanik Pula, and Rade Končar Zagreb. Manufacturers of mechanical and electrical plants produce their special systems, accessories, tools and equipment for dismantling and installation of assemblies from their manufacturing programs, which are not applicable to plants of other manufacturers. In addition, such systems are not sufficiently adapted and applied to field conditions, which is their main disadvantage. Some manufacturers have developed systems for technical maintenance and repairs on the principle of aggregate replacement of complete mechanical and electrical assemblies. This means that they deliver new or overhauled mechanical assemblies to the customer, where the need arises. They take over the complete existing assembly from the client and overhaul it, for extra charge. The innovative device solves the problems of competition (Petrov, 2016a).

The innovative company has gained the trust of customers. Very often it is engaged by foreign manufacturers of devices and equipment to carry out the installation of new devices or overhaul of existing circuits at the user's facility. The innovative company has a personal support and direct relationships with purchasers and service recipients. It is very fast to react on the ground and resolve the existing problems within 24 hours. Additionally, it acts preventively to avoid early failures and system crashes. 
The innovative company provides training to technical staff responsible for the correct plant operation. It develops plans for current and regular technical maintenance. All this provides the innovative company with a huge advantage when participating in public tenders for obtaining jobs.

\section{Part II - Business model}

\section{Target customers in 2017}

Target customers of the innovative device for dismantling and mounting assemblies for 2017 are: Electrical industry Montenegro, owners of commercial, passenger ships, cruise ships, war ships and ships carrying cargo (barges) and several private companies that provide services in the field of technical system maintenance.

For the purposes of the Electrical industry Montenegro (EPCG), the innovative company needs to supply an additional quantity of 17 sets of equipment for dismantling and assembly. The customer wants to have the devices at all locations where their plants are located. The locations of their systems are quite distant from one another. The other 13 sets of equipment are to be delivered to private companies engaged in overhaul of diesel generating sets, pump plants in the field and to owners of ships and vessels. There is also some interest from the steel mills and cement factories from neighboring countries.

\section{Description of the offer value to targeted customers}

Since this new product, a device for assembling and dismantling noteasily detachable equipment sets, has been on the market for a long time, it is fully known what new customers want and what they need. Their request for overhaul is to be performed on the plant site, to be of good quality, and with no damage to parts and assemblies. This innovative technology significantly reduces the price of the overhaul for $50 \%$ of the total overhaul price, which is very important for customers. The buyer has much higher costs if mechanical or electrical assemblies are disassembled, transported and overhauled at some Overhaul Institute and returned to the facility for installation. The price of the entire device is 6.000 Euros. In addition, the customer does not have high device maintenance costs. Additionally, the customer gets free on-site training of technical staff to be able to perform some simple repairs on their own, which is sometimes very important. 


\section{Sales channels to target customers}

So far, the innovative company has had direct relationships and personal support from customers for the sale of the new device for dismantling and mounting assemblies, a Know-How based-system. The company participated in published public tenders. The tender documentation was not only about the requirement of the lowest price but also about the quality of overhaul, duration of the execution of works and many other parameters. On that basis, the innovative company has always won contracts to mutual satisfaction. This significantly has contributed to the increased reliability of technical devices and systems (Šenk, 2016).

\section{Relations with target customers}

Relationships with customers are maintained through a personal support system. The company has direct relations with many customers, which proved to be the best way of cooperation (Rašković-Depalov, 2016). They have no significant costs in contacts with customers. They retain their customers with responsibility and professionalism. Customers expect to get a high-quality device (no complaints up to now) with quality repair services on site. If there are any unforeseen failures, the innovative company comes quickly to the site to solve the problem.

Based on years of experience and real needs, the innovative company proposes the specification of spare parts. Many spare parts are imported and foreign suppliers sometimes need considerable time to deliver their goods.

Bearing all this in mind, customers appreciate the planned activities of this innovative company and keep it in their operational systems. Service costs are quickly paid by the buyer.

\section{Revenues}

The innovative copany sells the finished product, a device for dismantling and installation and provides technical maintenance services to target customers. The revenue projections for the twelfth month are shown in Table 2. There are no restrictions on the production and service capacities. Customers accept the price in full (Ćelić, 2016). 
Table 2 - Projected revenues in the twelfth month Таблица 2 - Прогнозируемые доходы в XII месяце Табела 2 - Пројекција прихода у XII месецу

\begin{tabular}{|c|c|c|c|}
\hline PRODUCT / SERVICE & $\begin{array}{c}\text { MONTHLY } \\
\text { SALE }\end{array}$ & $\begin{array}{c}\text { SALES } \\
\text { PER PIECE }\end{array}$ & $\begin{array}{c}\text { TOTAL } \\
\text { REVENUE }\end{array}$ \\
\hline & PCS & (Currency) $€$ & Currency) $€$ \\
\hline A & 3 sets of devices & 6.000 & 18.000 \\
\hline B & $\begin{array}{c}\text { 1 technical maintenance } \\
\text { service }\end{array}$ & 12.000 & 12.000 \\
\hline IN TOTAL & & & 30.000 \\
\hline
\end{tabular}

\section{Key resources}

The innovative company has technical, financial, intellectual, marketing and human resources. It has more than 30 years of professional experience. In the work organization, the manufacturers of the components of the device for dismantling and assembling mechanical and electrical assemblies are very important. They are required to deliver device components of high quality. The new device as an innovative product was developed a few years ago, tested and put to use, which is proved by appropriate technical documentation on the development, design and quality of the device.

The innovative company has highly qualified and professional people to perform overhaul services. Professionals have a number of licenses and authorizations to work. Repair services are specifically agreed upon, depending on the type of plants, the scope of work, quantity of spare parts, locations of the facility, etc.

The description of the key resources is shown in Table 3 and Table 4 (investments to start the business).

Table 3-Description of the key resources: Team, intellectual property and material resources

Таблица 3 - Описание основных ресурсов: Команда, интеллектуальная собственность и материальные ресурсы

Табела 3- Опис кључних ресурса: тим, интелектуална својина и материјални ресурси

\begin{tabular}{|l|l|}
\hline & $\begin{array}{l}\text { Innovative team consists of: } \\
\text { 1. Academic, patent engineer, working on research and development, } \\
\text { design, mechanical and electrical systems, }\end{array}$ \\
DESCRIPTION & $\begin{array}{l}\text { 2. Specialist for overhauling thermal power plants, hydro power } \\
\text { plants, nuclear power plants and other complex technical systems, }\end{array}$ \\
$\begin{array}{l}\text { 3. Master of Science, a team of specialists in the installation and } \\
\text { repair of electric power systems, a specialist in power plants and } \\
\text { control. }\end{array}$ \\
\hline
\end{tabular}




\begin{tabular}{|c|c|c|c|}
\hline $\begin{array}{l}\text { INTELLECTUAL } \\
\text { PROPERTY }\end{array}$ & \multicolumn{3}{|c|}{$\begin{array}{l}\text { Device for dismantling and installation, after sales system Know-How. } \\
\text { The company intends to apply for patent protection, and after that to } \\
\text { go to the PCT protection. } \\
\text { The innovator has } 5 \text { world-recognized patents in the field, he is the } \\
\text { author of over } 90 \text { scientific papers published in national and } \\
\text { international journals of the highest category. He participated in many } \\
\text { scientific conferences in the country and abroad. He has worked on } \\
\text { many projects and scientific studies. Intellectual property and human } \\
\text { resources support their business model. }\end{array}$} \\
\hline $\begin{array}{l}\text { TECHNICAL } \\
\text { RESOURCES }\end{array}$ & \multicolumn{3}{|c|}{$\begin{array}{l}\text { The innovative company has capacity to produce devices for } \\
\text { dismantling and assembly that can meet all customer needs. The } \\
\text { subcontractor for the production of the mechanical component of the } \\
\text { device is Jeep Commerce Belgrade (delivery of quality materials), } \\
\text { high-quality machining is performed by Alatnica Lazarevic Belgrade, } \\
\text { and Nitro Jon company, Stara Pazova, perform thermo-chemical } \\
\text { processing of machine parts. The hydraulic component of the device } \\
\text { is performed by Sloga company, Nova Varos, while alternative } \\
\text { suppliers are companies Lincos from Hungary, and Womax and } \\
\text { Einhell from Germany. The unit for heating device parts is supplied by } \\
\text { the firm Teleoptik, Zemun. The innovative company is specialized in } \\
\text { performing a variety of services of technical maintenance. They are } \\
\text { equipped with special tools, fixtures, appliances and other equipment. } \\
\text { They also have official motor vehicles for the transport of the team, } \\
\text { parts and tools to the field. }\end{array}$} \\
\hline $\begin{array}{l}\text { MARKET } \\
\text { RESOURCES }\end{array}$ & \multicolumn{3}{|c|}{$\begin{array}{l}\text { In the last four years, they have sold } 20 \text { devices. In agreement with } \\
\text { our customers the plan is to sell another } 30 \text { sets of equipment in the } \\
\text { current year, following the production plan and delivery schedule. }\end{array}$} \\
\hline $\begin{array}{l}\text { FINANCIAL } \\
\text { RESOURCES }\end{array}$ & \multicolumn{3}{|c|}{$\begin{array}{l}\text { Innovative company achieves significant inflows by selling the device } \\
\text { for dismantling and installation, and by providing quality services of } \\
\text { technical system maintenance. The expected cash at the end of the } \\
\text { period amounts to } 120,030 \text { Euros, covering all the costs of the } \\
\text { business. }\end{array}$} \\
\hline \multicolumn{4}{|c|}{$\begin{array}{l}\text { Table } 4 \text { - Description of the key assets: Investments to start the business } \\
\text { Таблица 4- Описание основных активов: Инвестиции в запуск бизнеса } \\
\text { Табела } 4 \text { - Опис кључних ресурса: инвестиције за почетак пословања }\end{array}$} \\
\hline \multicolumn{2}{|c|}{ TYPE OF INVESTMENT } & DESCRIPTION OF INVESTMENT & Amount in $€$ \\
\hline \multicolumn{2}{|l|}{ Fixed assets } & $\begin{array}{l}\text { Investments whose effect is expected in the } \\
\text { period> } 1 \text { year }\end{array}$ & \\
\hline \multicolumn{2}{|l|}{ - Intangible assets } & $\begin{array}{l}\text { Investments in the development of products / } \\
\text { services } \\
\text { Investments in concessions, patents, } \\
\text { licenses and similar rights }\end{array}$ & 1.500 \\
\hline
\end{tabular}




\begin{tabular}{|c|c|c|}
\hline TYPE OF INVESTMENT & DESCRIPTION OF INVESTMENT & Amount in $€$ \\
\hline - Real Estate & $\begin{array}{l}\text { Investments in land } \\
\text { Investments in facilities }\end{array}$ & \\
\hline - Equipment & $\begin{array}{l}\text { Investments in machinery and equipment } \\
\text { Investments in vehicles } \\
\text { Investments in furniture } \\
\text { Investments in tools and fixtures }\end{array}$ & 30.000 \\
\hline Current assets & $\begin{array}{l}\text { Investments whose effect is expected in the } \\
\text { period }<1 \text { year }\end{array}$ & \\
\hline - Supplies & $\begin{array}{l}\text { Investments in raw materials } \\
\text { Investments in goods } \\
\text { Investments in spare parts }\end{array}$ & \\
\hline •Prepaid expenses & $\begin{array}{l}\text { Costs that must occur before the start of } \\
\text { generating revenue }\end{array}$ & \\
\hline - Cash Money & $\begin{array}{l}\text { The necessary funds in the account / cash } \\
\text { register }\end{array}$ & \\
\hline Total Cost: & & 31.500 \\
\hline
\end{tabular}

\section{Key activities}

The innovative company has provided that the production capacities of the key partners (subcontractors) are not a bottleneck. They have established such a work system to plan in advance the production and to order in advance the amount of equipment necessary to be delivered to the market. The costs of the device production are covered by customer's advanced partial payment.

The device for dismantling and installation of mechanical and electrical assemblies must be of high quality and made according to all requirements of technical documentation, which is the responsibility of producers of device components - the key partners. This satisfies the placement of the device on the market and customer requirements. The current device customers are very satisfied with the new device and the possibilities that the device allows in overhauling assemblies. The sales promotion and marketing of the innovative device were very successful in direct relations and on the Internet (Zagorac-Knežević, 2016). The higher sales performance was achieved in direct relations with customers. The whole team was maximally engaged while the negotiations with end customers were done by the team manager. In the previous work, the innovative 
company has had no complaints for the new device and the repair service.

\section{Key partners}

The key partners for the production of the device for dismantling and installation of not-easily detachable mechanical and electrical assemblies are the producers of the device components. Machine components of the device for dismantling and assembling are produced by the companies engaged in the manufacture of mechanical component and device parts, on the basis of the device technical documentation. In this process, tolerances or accuracy of parts are very important as well as their chemical-thermal treatment. Jeep - Commerce, Belgrade, supplies the material; parts are machined in Alatnica-Lazarević, Belgrade; and chemical-thermal treatment of mechanical elements is carried out by Nitro Jon, Stara Pazova.

The hydraulic part and the heating unit are purchased on the market from known and reputable manufacturers who supply them with the product quality assurance reports and certifications. The hydraulic part is delivered by Sloga, Nova Varoš, and other companies such as Lincoss from Hungary or Einhell and Womax from Germany. The heating unit is supplied byTeleoptik, Zemun. In this way, the innovative company provides high quality of its product. The key partners are very responsible so that there are no delays in deliveries to customers.

\section{Cost structure}

In the production of the device, significant funding goes for: materials, mechanical and chemical-thermal treatment of mechanical components of the unit, the hydraulic unit and the heating unit. In addition, there are also fixed costs in the company business. The cost of communications with customers is not particularly pronounced (Zagorac-Knežević, 2016). The variable and fixed costs are provided in Table 5. 
Table 5 - Variable and fixed costs

Таблица 5 - Вариабельные и фиксированные расходы

Табела 5 - Варијабилни и фриксни трошкови

\begin{tabular}{|c|l|c|c|}
\hline \multicolumn{2}{|c|}{ VARIABLE OPERATING COSTS } & \multicolumn{1}{c|}{ A } & B \\
\cline { 3 - 4 } & (Currency) $€$ & (Currency) $€$ \\
\hline \multicolumn{3}{|c|}{ VARIABLE COSTS (per unit of product) } \\
\hline 1. & The selling price of the product / service & $\begin{array}{c}\text { The selling } \\
\text { price set } \\
\text { device }\end{array}$ & $\begin{array}{c}\text { Price of services } \\
\text { per one } \\
\text { engagement }\end{array}$ \\
\hline 2. & \multicolumn{2}{|c|}{6.000} & 12.000 \\
\hline 2.1 & Cost of raw materials / materials & 1.800 & \\
\hline 2.2 & Costs of distribution and sales & 200 & \\
\hline 2.3 & The costs of packaging & 100 & 1.000 \\
\hline 2.4 & Energy costs & 100 & 1.000 \\
\hline 2.5 & Variable operating costs & 650 & 11.000 \\
\hline 2.6 & Costs of communication with customers & 150 & \\
\hline 3. & $\begin{array}{l}\text { TOTAL VARIABLE COSTS } \\
\text { PER UnIT OF PRODUCT / SERVICE }\end{array}$ & 3.000 & \\
\hline 4. & TOTAL PRICE OF-VARIABLE & 3.000 & \\
\hline
\end{tabular}

\begin{tabular}{|c|c|c|}
\hline FIXED MONTHLY OPERATING COSTS & Currency $€$ & Comments \\
\hline Fixed salaries of the employees & 2.400 & $\begin{array}{c}3 \text { employees } \\
\text { within the team }\end{array}$ \\
\hline - Electricity & 100 & \\
\hline - Depreciation & 350 & \\
\hline \multicolumn{3}{|l|}{ Other fixed costs: } \\
\hline - Accounting services & 50 & \\
\hline - Telephone / internet & 100 & \\
\hline - Maintenance / Cleaning & 100 & \\
\hline \multicolumn{3}{|l|}{ - Other } \\
\hline TOTAL FIXED COSTS & 3.100 & \\
\hline
\end{tabular}


Contribution coverage $=$ The selling price of the unit-Variable unit costs Contribution coverage $=6.000 €-3.000 €=3.000 €$

Breakeven point $=$ Fixed costs $/$ contribution to cover

Breakeven point $=3.100 / 3.000=1.033 €$

The breakeven point is reached by selling two sets of equipment for dismantling and assembly.

\section{Part III - The value of the company}

\section{Pitch to investors}

The innovative company performs overhauls of plants in the field, using its new device simply, with good quality and without damaging parts. This team is very professional. It has been selling the device for 4 years, with a plan to sell 300 sets of equipment over the next 5 years (RaškovićDepalov, 2016).

\section{Expansion Potential - Scalability}

The new device has broad application possibilities. The innovative company is sure that it can be successful in the market for the next 10 years. The device is not easy to copy or reproduce. It takes a lot of knowledge in the field of materials and many years of experience in the technical maintenance of systems. In the first year of production, the business model requirements regarding research, development, certification and implementation of the new device were met. The breakeven point was realized with the sale of the first 2 device sets. In the first year, 5 sets were sold, which means that certain financial profit was made. In addition, overhaul services largely contributed to the increase in profits. This shows that the project is highly profitable. It has been successful on the market for 4 years. The device has various possibilities of application and may satisfy an increase in requests and the large number of customers, without changing the application itself. The aim is to achieve linearity in the speed of response to requests from customers (Petrov, 2016a), (Petrov, 2016b). 


\title{
The parameters for determining the value of the company
}

For the first 12 months, the innovative company is planning to sell 30 sets of equipment. The unit price is $6.000 €$. The variable costs per 1 unit amount to $€ 3,000$. The fixed cost is $3.100 €$. One repair service is planned at a price of $12.000 €$. Variable costs amount to $1,000 €$ (travel expenses, accommodation and daily allowance). The planned earnings are 54.230 Euros. The income statement is presented in Table 6.

\author{
Table 6 - Balance sheet \\ Таблица 6 - Баланс \\ Табела 6 - Биланс успеха
}

\begin{tabular}{|c|c|c|c|}
\hline \multicolumn{4}{|c|}{$\begin{array}{l}\text { INCOME STATEMENT FOR THE FIRST } 12 \text { MONTHS OF OPERATIONS } \\
\text { (after completion of development) }\end{array}$} \\
\hline BUSINESS INCOME & $\begin{array}{l}\text { Currency } \\
€\end{array}$ & OPERATING COSTS $€$ & Currency $€$ \\
\hline Revenues from sales & & 1. VARIABLE COSTS & \\
\hline A -1 Device set & 180.000 & 90.000 & 90.000 \\
\hline \multirow[t]{2}{*}{$\begin{array}{l}\text { B- } 1 \text { service of theplant } \\
\text { overhaul }\end{array}$} & 12.000 & 1.000 & 1.000 \\
\hline & & 2. FIXED COSTS & 37.200 \\
\hline \multicolumn{4}{|l|}{ Other income } \\
\hline TOTAL OPERATING INCOME & 192.000 & $\begin{array}{l}\text { TOTAL OPERATING } \\
\text { COSTS }\end{array}$ & 128.200 \\
\hline \multicolumn{4}{|l|}{ OPERATING PROFIT / LOSS } \\
\hline \multicolumn{2}{|l|}{ FINANCE INCOME } & \multicolumn{2}{|l|}{ FINANCIAL EXPENSES } \\
\hline Interest income & & Interest expense & \\
\hline Other finance income & & $\begin{array}{l}\text { Other financial } \\
\text { expenses }\end{array}$ & \\
\hline \multicolumn{4}{|l|}{ FINANCIAL PROFIT / LOSS } \\
\hline \multicolumn{3}{|c|}{ PROFIT I LOSS BEFORE TAXATION } & 63.800 \\
\hline \multicolumn{3}{|l|}{ INCOME TAX (15\%) } & 9.570 \\
\hline \multicolumn{3}{|c|}{ PROFIT I LOSS FOR THE PERIOD OF 12 MONTHS } & 54.230 \\
\hline
\end{tabular}

In the previous period (Year 0 ), the innovative company sold 20 sets of equipment at a price of 6,000 Euros each. One overhaul service was performed. The cash outflow for variable costs was in the amount of 
64,000 Euros, which amounts to 168,000 Euros. The fixed costs were 12,400 Euros. The profit was 91,600 Euros. In the current year (Year 1), there is a plan to sell 30 device sets and to perform one overhaul service. The plan is to purchase a service vehicle and equipment in the amount of 30,000 Euros. The planned total earnings are 28,430 Euros.

The cash flows for the previous year and the current year operations are given in Table 7.

Table 7 - Cash Flow

Таблица 7 - Потоки денежных средств Табела 7 - Новчани токови

\begin{tabular}{|c|c|c|}
\hline \multicolumn{3}{|l|}{ ESTIMATED CASH FLOWS } \\
\hline & Years & Years \\
\hline & 0 & 1 \\
\hline \multicolumn{3}{|l|}{ Cash flow from operating activities } \\
\hline 1. Cash inflow from products and services & 168.000 & 192.000 \\
\hline \multicolumn{3}{|l|}{ 2. Other cash inflow } \\
\hline 3. Outflows from variable costs & 64.000 & 91.000 \\
\hline $\begin{array}{l}\text { 4. Outflows of fixed costs } \\
\text { (excluding depreciation }\end{array}$ & 12.400 & 33.000 \\
\hline \multicolumn{3}{|l|}{ 5. Other outflows } \\
\hline $\begin{array}{l}\text { I Net cash flow from operating activities } \\
\text { (1st }+2 \text { nd-3rd-4th-5th). }\end{array}$ & 91.600 & 68.000 \\
\hline \multicolumn{3}{|l|}{ Cash flow from investing activities } \\
\hline \multicolumn{3}{|l|}{ 1. Sale of property, plant and equipment } \\
\hline \multicolumn{2}{|l|}{ 2. Purchase of property, plant and equipment } & 30.000 \\
\hline $\begin{array}{l}\text { II Cash flows from investing activities } \\
(1 .-2 .)\end{array}$ & & -30.000 \\
\hline \multicolumn{3}{|l|}{ Cash flow from financing activities } \\
\hline \multicolumn{3}{|l|}{ 1. Capital Increase } \\
\hline \multicolumn{3}{|l|}{ 2. The resulting credits } \\
\hline \multicolumn{3}{|l|}{ 3. Donations, subsidies, grants } \\
\hline \multicolumn{3}{|l|}{ 4. Loan repayment } \\
\hline 5. Income tax & & 9.570 \\
\hline $\begin{array}{l}\text { III Net cash flow from financing activities } \\
(1 \mathrm{st}+2 \mathrm{nd}+3 \text { rd-4th-5th). }\end{array}$ & & -9.570 \\
\hline $\begin{array}{l}\text { IV Net cash inflow / outflow period } \\
(I+\text { II + III) }\end{array}$ & & 28.430 \\
\hline V-In Cash at the beginning of the period & 91.600 & 91.600 \\
\hline Cash at the end of the period (IV + V) & & 120.030 \\
\hline
\end{tabular}




\title{
Appendix: Documentation on services of performed overhaul
}

\author{
Appendix 1 Installation of the geared motor \\ in MHE- Podgor-Montenegro
}

\section{ZAPISNIK O ISPORUCI I IZVRŠENIM RADOVIMA MONTAZ̆E ZUPČASTOG REDUKTORA TIP FLENDER WGW SAN 280/SO-NEMAC̆KA, FAB. BR. 88212-0 1078/22410 и MHE PODGOR}

Na osnovu Ugovora br.3541 od 18.10.2013 između Elektroprivrede Crne Gore (naručilac radova) (isporuð̌ilac i izvršilac radova), izvršena je
nabavka $i$ isporuka zupčastog reduktora tip Flender WGW SAN 280/SO-Nremačka, fab.br. 88212-0-1078/22410.

Isproručilac reduktora imao je obavezu da montira zupcasti reduktor u MHE Podgor.

Dana 10.04.2014. stručna lica iz firme Oc, izvršila su demontažu neispravnog reduktora u hidroelektrani Podgor. Izvršene su sve pripreme i radovi radi montaže novog reduktora. Proizvođač reduktora sipao je originalno ulje u reduktor Total Carte EP 220. Na novi reduktor ugradeni su ispravni delovi na pogonskom vratilu reduktora glavčin Flender spojnice tip N-EUPEX velicine A 480 i na gonjenom vratilu reduktora prirubnica Flender- lamelaste spojnice tip Arpex, velicina 270, serija K 430.

Izvršena je zamena elastičnih gumenih umetaka (10 komada) u spojnici tip Flender N-Eupex A 480.

Izvršena je nivelacija i centracija novog zupěastog reduktora na temelju, a nakon toga izvršena je provera da li je reduktor evrsto vezan za temelj s obzirom da nisu dozvoljena pomeranja sklopa u toku rada.

Prema tehničkoj dokumentaciji za montažu reduktora i flenderovih spojnica, izvršena je provera razmaka prirubnica na Flender spojnici tip Arpex velicina 270. Propisano je da se taj razmak meri na 6 mernih mesta $i$ da se nalazi u granicama od $S 1 \min =22.5 \mathrm{~mm}$ do $S 1 \max =23.5 . \mathrm{mm}$. Izmerene vrednosti nalazile su se u tim granicama.

Propisane vrednosti razmaka između glavčina spojnice tip Flender moraju se nalaziti u granicama $\mathrm{S}=5$ do $10 \mathrm{~mm}$, sto je zadovoljeno kod montaže novog reduktora. U toku montaže novog reduktora zadovoljeni su svi uslovi koji su propisani po tehničkoj dokumentaciji kao što su momenti pritezanja zavrtnjeva (vijaka), spajanje ostalih delova instalacije na reduktor-cevi za hlađenje reduktora, merni instrumenti i ostalo.

Nakon izvršene montaže reduktora, mini hidroelektrana je puštena u probni rad $i$ izuršena su testiranja rada na razlicitim režimima rada i opterećenjima elektrane. Utvrđeno je, da elektrana ispravno radi. Radne temperature ulja u reduktoru nalaze se u propisanim granicama. Reduktor mirno radi bez povišenih vibracija i buke.

Nakon svih aktivnosti MHE Podgor puštena je u oprerativni rad u sistemu Elektroprivrede Crne Gore.

Naručilac radova nema primedbi na isporuceni sklop, rezervne delove i izvršene radove. Preuzeo je obavezu da će se pridržavati svih normi u garantnom roku.

ZA MHE PODGOR

U Podgoru, 10.04.2014.

Zapisnik dostavljen:

-HE Perucica,

-Službi MHE, 


\section{Appendix 2 - Minutes on the repair of damage to the assemblies of the MHE Montenegro}

Na osnovu Poziva br. 57/06 na otvoreni postupak javne nabavke od 26.10.2013. za rešavanje problema grejanja ležaja u MHE "PODGOR" u periodu od 11.12. do 13.12.2013. izvršeni su sledeći radovi

1. Demontaža elastičnih spojnica tipa Flender ARPEX K 430-Veličina 270, koje povezuju multiplikator i generator MHE

sa osovine zamajca postrojenja,

kotrljajnih ležajeva tipa $S K F 22220 H L K+H 320$ sa osovine zamajca,

Vizuelni pregled demontiranih delova, osovine zamajca, elemenata elastične spojnice, kotrljajnih ležajeva, kućišsa i postolja ležajeva zamajca,

Utvrđivanje uzroka pregrejavanja kotrljajnih ležajeva zamajca,

Izrada alata za propisnu montažu čaura (hilzni) kotrljajnih ležajeva zamajc

Montaža novih kotrljajnih ležajeva sa pripadajućim hilznama $22220 \mathrm{EK}+H 320$. Delove je obezbedio narucioc posla u skladu sa zahtevima tehnicke dokumentacije,

Montaža elastix̌nih spojnica tipa Flender

(rpex 430 veličina 270 , između zamajca i reduktora

Centriranje zamajca u odnosu na multiplikator i generator MHE

12. Pustanje MHE u probni rad.

Merenje vibracija (prema planu merenja) u tri međusobno okomita smera: vertikalni smer, bočn smer $\mathrm{i}$ uzdužni smer. Merenje vibracija izvršeno je na određenim mernim mestima na: turbini,

4. Izvršena je laserska provera centričnosti sklopova MHE. Na osnovu izmerenih nivoa vibracija nije

(kao to je naznaceno u datoj ponudi za sale ležaja). Izveštaji o merenju dostavljeni su naruciocu posla, firmama ponudi za sanaciju grejanja

(izveštaj če dostaviti firma

15. Nakon izvšenog testiranja konstatovano je da se MHE-Podgor može pustiti u operativni rad.

16. Puštanje u operativni rad MHE-Podgor u sistem EPCG.

Mast za podmazivanje ležajeva tipa Shell Alvania $R L-3$ obezbezbedio je izvođač radova.

Naručioc posla obezbedio je odgovarajuće rezervne delove $i$ uslove rada: stručno lice za rad u elektrani-puštanje u pogon elektrane, rukovanje sa razvodnim ormarima, elektriěnim uredajima, ispravnu kransku dizalicu i sajle za podizanje zamajca. Garancija na izvedene rado

Naručioc posla ima obavezu da u roku od 7 dana izvrši uplatu za izvršene usluge u celosti (pošto nije uplaćen avans) za izvodenje radova firmi

koju je angažovala firma Nevim partijama radova un tenderu.

ZA MHE-PODGOR

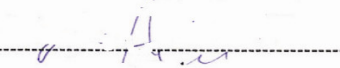

U Podgoru-Crna Gora, 13.12.2013

Zapisnik dostavljen:
-HF,-Perućica-MHE-Podgor,

$-$ 


\section{Conclusion}

The paper presents the experience in the development of an innovation in terms of its scientific verification and its placement on the market. The techno-economic analysis of the new device was carried out.

An example of developing a business model based on the innovative product is given.

The new device for dismantling and assembling the parts of not-easily detachable assemblies on mechanical and electrical installations has enabled the company to develop an innovative new technology of on-site overhaul, new ways of organizing work and the execution of light and intermediate level repair, general revision and overhaul in field conditions. In addition to the placement of the device on the market, the innovative company carries out planned system maintenance and specialized measurements: measurement and analysis of vibrations - vibrodiagnostic assessment of the technical condition of the system, the laser alignment of assemblies, thermal imaging, developing various types of software, delivery and installation of modern monitoring systems, and others. The construction of the new device combines two basic functions: dismantling and assembly of assemblies. The device is modular and consists of 3 parts: the mechanical part (mechanical components of the device), the hydraulic part and the unit for heating parts that are dismantled or assembled.

It is easy to use, there is no possibility of damage to parts during operation and it is easy to carry. The unit weighs $25 \mathrm{~kg}$. This universal device enables overhauling assemblies of different manufacturers in the field conditions. It has a wide range of applications, which until now was not the case.

The universality of the device application is achieved through various combinations of the constituent parts of the device - it does not mean that the number of component parts increases, but that individual components are constructed and adapted to cover different sizes and dimensions of various assemblies to be overhauled.

The device is intended for the external dimensions of assemblies in the range of $\varnothing 100-1000 \mathrm{~mm}$, external shaft diameter $\varnothing$ from 50 to $300 \mathrm{~mm}$, for extremely large overlaps in the firm shaft - aperture fitting to $0.02 \mathrm{~mm}$ The length of fitting can reach up to $300 \mathrm{~mm}$. The dimensions smaller than the above measures do not represent a problem for dismantling and assembly since they can be done with bearing pullers and spatial tools and kits. 
The assembly weight is not a problem for the implementation of the new device, because assemblies are pulled up, moved, and pulled down back to their original position by means of various cranes in aggregate rooms where overhaul is carried out.

In addition to the new device delivered, end customers are provided with technical maintenance service, delivery of spare parts and training of technical personnel.

The new device reduces the cost of plant maintenance up to $50 \%$ compared to earlier overhaul technologies, when assemblies were transported to specialized workshops and overhaul institutes. The time required to perform overhaul is significantly reduced. For example, if the intermediate-level repair of a mini hydro power plant of $500 \mathrm{KW}$ used to take 30 days, now overhauling can be executed in 15 days with the overhaul costs halved.

In the period from 2002 to 2016, in the system of the Electrical industry Montenegro, higher overhaul levels in 18 mini hydroelectric power plants were carried out according to the plans. On some systems, overhauls were carried out several times, since the hydro power plants are in continuous operation, because of the huge influx of water in the operation season and opportunities for major electric power generation. This enables the customer to realize substantial profits, with minimal maintenance costs. In addition, the customer has gained significant financial resources for the purchase of new energy systems to replace the existing old systems or for the purchase and installation of systems on new locations.

The innovative company enabled similar gains to other customers as well.

\section{References}

Ćelić, Đ., 2016. Trening u okviru projekta Takmičenja za najbolju tehnološku inovaciju NTI-2016. Beograd: Privredna komora Srbije.

Petrov, V., 2016a. Trening u okviru projekta Takmičenja za najbolju tehnološku inovaciju NTI-2016. Novi Sad: Fakultet tehničkih nauka u N. Sadu.

Petrov, V., 2016b. Trening u okviru projekta Takmičenja za najbolju tehnološku inovaciju NTI-2016. Beograd: Privredna komora Srbije.

Rašković-Depalov, V., 2016. Trening u okviru projekta za Najbolju tehnološku inovaciju NTI-2016. Beograd: Privredna komora Srbije.

Šenk, V., 2016. Trening u okviru projekta Takmičenja za najbolju tehnološku inovaciju NTI-2016. Beograd: Privredna komora Srbije.

Tehnička dokumentacija firme Flender, 1975. Nemačka.

Tehnička dokumentacija za MHE, 1980. EPCG. 
Zagorac-Knežević, S., 2016. Trening u okviru projekta Takmičenja za najbolju tehnološku inovaciju NTI-2016. Beograd: Privredna komora Srbije.

Žegarac, N., 2012a. Tehnička dokumentacija - Uređaj za demontažu i montažu teško rastavljivih mašinskih i elektro sklopova. Beograd.

Žegarac, N., 2012b. Homologacija uređaja za demontažu i montažu delova teško rastavljivih sklopovima na mašinskim postrojenjima. Beograd: Alatnica Lazarević.

Žegarac, N., 2012. Izveštaj o merenju i analizi vibracija nakon generalnog remonta MHE. Podgorica. Crna Gora.

Žegarac, N., 2013. Izveštaj o merenju vibracija nakon generalnog remonta u MHE R. Crnojevića, Crna Gora.

Žegarac, N., Zuber, N., 2015. Merenje i analza vibracija nakon generalog remonta u MHE Podgorica. Crna Gora.

ОПЫТ В РАЗВИТИИ ИННОВАЦИЙ С ТОЧКИ ЗРЕНИЯ НАУЧНОЙ ВЕРИФИКАЦИИ И ПРОДВИЖЕНИЯ ГОТОВОЙ ПРОДУКЦИИ HA PЫHKE

Никола П. Жегарац

Сербская академия изобретателей и ученых, г. Белград,

Республика Сербия

ОБЛАСТЬ: инжиниринг, энергетика, судостроение, автомобильная промышленность, военная промышленность, инновации, экономика

ВИД СТАТЬИ: оригинальная научная статья

ЯЗЫК СТАТЬИ: английский

Резюме:

В данной статье описано инновационное монтажнодемонтажное устройство сложно разбираемых узлов машиностроительного и электротехнического оборудования, разработанное для условий полевого ремонта. Новизна состоит в том, что с помощью данного устройства намного ускорен процесс сборно-разборочных работ, а возможность повреждений практически исключена. Это переносное устройство, которое отличается легкостью в использовании. Оно применяется на всех этапах полевого ремонта любых видов станций и сооружений.

Данное устройство присутствует на рынке сбыта уже 4 года. Предполагаемые сроки его эксплуатации составляют 10 и более лет. При разработке данного монтажно-демонтажного устройства для машиностроительных и электротехнических узлов, были учтены все выявленные за время многолетнего опыта в области содержания и ремонта станций и сооружений 
проблемы, в частности невозможность выполнения разборочносборочных работ в условиях полевого ремонта.

Инновационное устройство обеспечило возможность развития новой технологии ремонта станций и сооружений, внедрены новые методы организации и выполнения ремонтных работ. Благодаря большому опыту и знаниям команды разработчиков, для осуществления идеи не понадобилось много времени (потребовалось всего 6 месяцев для осуществления целого проекта).

Продажа настоящего устройства производится в конфииденциальном порядке, оговоренном договорными обязательствами, которые подразумевают нераздлашение информации о конструкции, а также инструкции по эксплуатации устройства. В настоящий момент в Институте интеллектуальной собственности города Белград оформляется защита интеллектуальной собственности данного устройства, и по его завершении планируется подача международной заявки на патент (защита РCT).

Ключевые слова: инновация, новое устройство, монтажнодемонтажные работы, сложно разбираемые узлы, ремонт, машиностроительные и электротехнические сооружения, миниГЭС, судостроение, военная промышленность, бизнес-модель, компания по инновационным проектам, технико-экономическое обоснование.

ИСКУСТВА У РАЗВОЈУ ИНОВАЦИЈЕ СА АСПЕКТА НАУЧНЕ ВЕРИФИКАЦИЈЕ И ПЛАСМАНА ГОТОВОГ ПРОИЗВОДА НА ТРЖИШТЕ

Никола П. Жегарац

Српска академија изумитеља и научника, Београд, Република Србија

ОБЛАСТ: инжењеринг, енергетика, бродоградња, аутомобилска индустрија, војна индустрија, иновације, економија

ВРСТА ЧЛАНКА: оригинални научни чланак

ЈЕЗИК ЧЛАНКА: енглески

\section{Сажетак:}

Иновативни уређај за демонатжу и монтажу делова тешко растављивих склопова на машинским и електропостројењима у теренским условима ремонта омогућава брзу и ефькасану демонтажу и монтажу делова, без могућности оuтећења. Једноставан је за употребу и лако се преноси. Може се примени- 
ти за све врсте постројења и више нивое ремонта у теренским условима рада.

Уређај се налази на тржишту четири године, а очекује се да ће се користити наредних 10 година, а вероватно и дуже. Током дугогодишњег рада на пословима одржавања постројења било је много проблема у ремонту, па је развијен уређај за демонтажу и монтажу машинских и електросклопова. Многи склопови нису могли бити демонтирани и монтирани у теренским условима рада. Нови уређај омогућио је да се развије нова технологија ремонта постројења на местима где су инсталирана, затим нови начини рада у организацији и извршењу ремонта. Оठ идеје до реализације уређаја прошло је само 6 месеци, пошто тим има велико искуство на овим и сличним пословима. Иновативни уређај купцима се испоручује уз уговорне обавезе о продаји уређаја и ремонту система, а дефинише се и заштита тајности конструкције и примене уређаја.

У току је поступак заштите уређаја код Завода за интелектуалну својину у Београду, а након тога биће поднета и меЂународна пријава за патентну заштиту (заштита РCT).

Кључне речи: иновација, нови уређај, демонтажа и монтажа, тешко растављиви склопови, ремонт, машинска и електропостројења, мини- хидролектране, бродоградња, војна индустрија, пословни модел, иновативна компанија, техно-економска анализа.

Paper received on / Дата получения работы / Датум пријема чланка: 26.10.2016. Manuscript corrections submitted on / Дата получения исправленной версии работы / Датум достављања исправки рукописа: 27.11.2016.

Paper accepted for publishing on / Дата окончательного согласования работы / Датум коначног прихватања чланка за објављивање: 29.11.2016.

(c) 2017 The Author. Published by Vojnotehnički glasnik / Military Technical Courier (www.vtg.mod.gov.rs, втг.мо.упр.срб). This article is an open access article distributed under the terms and conditions of the Creative Commons Attribution license (http://creativecommons.org/licenses/by/3.0/rs/).

() 2017 Автор. Опубликовано в «Военно-технический вестник / Vojnotehnički glasnik / Military Technical Courier» (www.vtg.mod.gov.rs, втг.мо.упр.срб). Данная статья в открытом доступе и распространяется в соответствии с лицензией «Creative Commons» (http://creativecommons.org/licenses/by/3.0/rs/).

() 2017 Аутор. Објавио Војнотехнички гласник / Vojnotehnički glasnik / Military Technical Courier (www.vtg.mod.gov.rs, втг.мо.упр.срб). Ово је чланак отвореног приступа и дистрибуира се у складу са Creative Commons licencom (http://creativecommons.org/licenses/by/3.0/rs/).

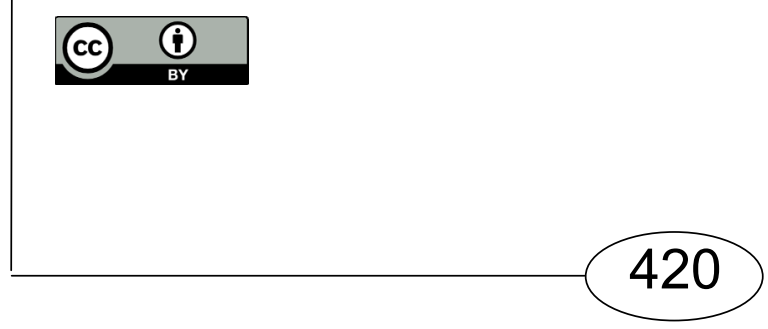

